\title{
FARMERS' GUIDANCE FOR RECYCLING AGRICULTURAL WASTES TO PRODUCE ANIMAL FEED
}

\author{
Mouhamed el hweity,. ${ }^{\text {(a) }}$ Galila a.m.a darwish,. ${ }^{\text {(b) }}$ Bakr .a.a,. ${ }^{\text {(b) }}$ Abd - elhamid, a.a,. (c) \\ Osama hassan mohamed ${ }^{(b)}$ \\ (a) depart., faculty of agric.; mounofiya univ,mounofiya; \\ (b) regional center for food and feed, agricultural research center, giza, egypt. \\ (c) institute for animal production, agricultural research center, giza, egypt.
}

\section{ABSTRACT}

he increasing expansion of water hyacinth plant activity over year has led to the accumulation of large quantity their in the Nile River due to prohibit a lot of rile water and light from organisms living in the Nile, and consuming nile water. Recently, the world used water hyacinth leaves to absorbe the metal ions from waste water. In this study we used this to up- grade nutritional value of some lignocellulosic matertials such as rice straw and banana leaves. The lignocellulosic residues can be used without any chemical or biotechnology pretreatment (control) or can be hydrolyzed before any fermentation, then the subsequent can result in a product with high protein content as well as high digestibility compared to non added residues. In this study, we made mixture combination water hyacinth leaves to rice straw or banana leaves with different ratios $(5,10,15,20,25$ and $30 \mathrm{~g}$ water hyacinth leaves/100g rice straw or banana leaves). All treatments gave a good results, but treatment added $30 \mathrm{~g}$ water hyacinth leaves / $100 \mathrm{~g}$ rice straw or banana leaves is the better than all. The increasing in protein content from $2.30 \%, 12.50 \%$ (control) to $10.00 \%, 17.10 \%$ and decreasing in fiber fraction sepically, cellulose and lignin. Cellulose decreased from $33.30 \%$, $26.30 \%$ to $22.00 \%, 19.35 \%$ and lignin decreased from $11.60 \%, 8.50 \%$ and $5.95 \%$, $5.35 \%$ in rice straw and banana leaves, respectively. In vitro digestibility studies indicated significantly $(\mathrm{P}<0.05)$ higher values for treatment added $30 \%$ water hyacinth leaves in the rice straw and banana leaves, respectively, to produce feed non traditional for animals.

Pleurotus ostreatus was used to upgrade nutritional value of rice straw, banana leaves and water hyacinth leaves by using different amounts of Pleurotus ostreatus inoculum, in solid state fermentation technique. The chemical composition and in vitro digestibility of the resulted protein enriched product were determined. Cellulose, hemicellulose and lignin showed gradual decrease with increasing inoculums of Pleurotus ostreatus, however, in vitro disappearance increased.

Keywords:Rice straw, Banana leaves, Water hyacinth leaves, Pleurotus ostreatus, in vitro disappearance.

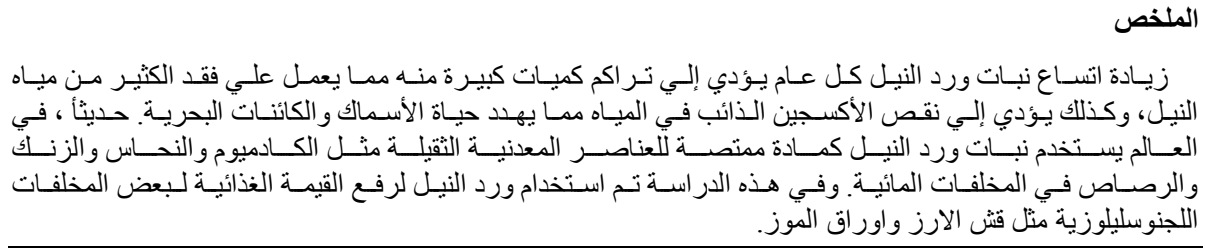

Issued by Environmental Studies and Researches Institute (ESRI), University of Sadat City 


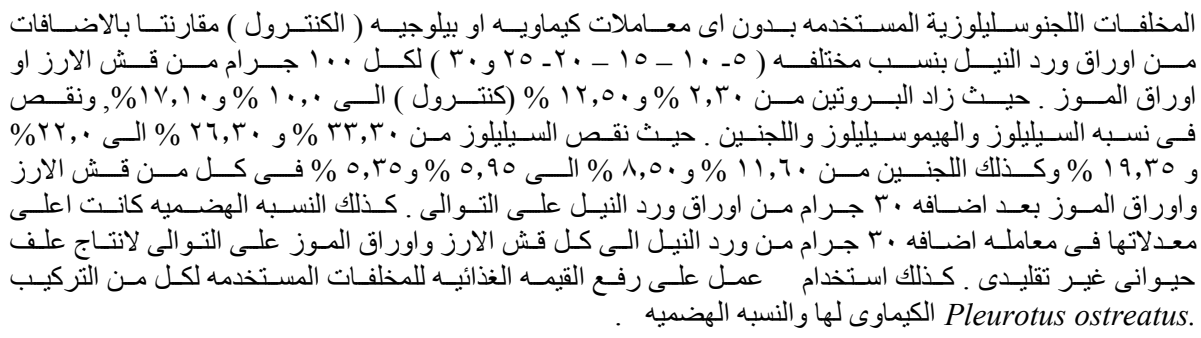

\section{INTRODUCTION}

In Egypt, there is a limitation in the cultivated area and a high increasing in the population rate. Thus, there is a serious shortage in animal feeds, causing high negative effects on live stock production. Therefore, it is very important to use unconventional sources as animal feeds. Agriculture wastes and by products seem to overcome partially this problem.

In Egypt, there is a lack in protein feed ingredient for animal feeding. So, many studies were carried out to improve the quality of protein feed ingredient (EL-Sayed et al., 2002), or to use new sources of protein (Mohi El-Din et al., 2008; Leupp et al., 2009; May et al., 2009; Shwerab et al., 2010 and Etman et al., 2011) in ruminant rations. Agricultural crop residues are still grown dramatically causing severe pollution problems, with a production of approximate 35 million tons on DM basis per year.Traditionally, they are removed to be used as fodder, cooking fuel, fencing to be burned. Recently, return of residues into the field, such as leaving crop residues on the soil surface, incorporating them into the soil, has been popular in enhancing soil quality.

Rice straw represents an important summer crop by-product in Egypt. About 3.5 million tons of rice straw and 0.5 million tons of rice hulls are produced every year from the rice fields and rice milling process respectively. There is no practical use for these by-products, up till now, except for fuel. This paper reviews some research results relevant to the use of rice straw and rice hulls as feeds for ruminants in Egypt.

Chemical composition of banana wastes is very close to that of berseem. Banana wastes can play an important role in covering some nutrients requirements of animals (Abd-EL-Gawad et al., 1994) especially they are available in Egypt all over the year (Khattab et al., 2000). The native agricultural crop residues are slowly digested by reumines microorganisms and considered a poor fermentation substrates. Thus, physical (milling) and addition water hyacinth leaves, treatments of these substrates are necessary to disrupt the physical fine structure of cellulose as well as to remove lignin .

Water hyacinth plant was used to adsorption to several cations from waste water. The dried leaves of water hyacinth plant were used at different adsorbent metal ions ratios, and investigated the influence of $\mathrm{pH}$, content time, metal concentration and TYV 
absorbent loading weight on the removal process (Abia et al., 2002; Singh et al, 2005; Abdel-Ghani and El-chaghaby, 2007).

Many researchers have studied chemical and biological pretreatments for enhancing conversion of lignocellulosic materials to protein enriched product (Vijaya et al 2007). Pleurotus pulmonarius via solid state fermentation technique, through enhancement of in vitro digestibility and protein content an expense of crude fiber and fiber fraction contents .

The main objective of the current study is concerned with nutritional value upgrading of rice straw, banana leaves and water hyacinth leaves to protein enriched by-product via using combined mixed of them and white rot fungi (Pleurotus ostreatus ) in solid state fermentation process

\section{MATERIALS AND METHODS}

\section{MATERIALS}

Rice straw and banana leaves were obtained from the experimental farm of Agricultural Research Center, Giza, Egypt. They were rinsed with water, air dried, then cut into about $1-2 \mathrm{~cm}$. The chopped rice straw and banana leaves were dried at $70{ }^{\circ} \mathrm{C}$ for 24 hour.

White rot fungi, namely Pleurotus ostreatus NRRL-2366 was obtained from the National Center of Agricultural Utilization Research Service, US., Department of Agricultural, Peoria, Illinois, USA. The strain was maintained on potato dextrose agar medium (Difco Manual, 1979), then store at $4^{\circ} \mathrm{C}$.

\section{MICROBIOLOGICAL METHODS}

\section{PREPARATION OF GRAINS SPAWN}

To prepare grains master spawn, wheat seeds or sorghum seeds were used.

Seeds were cleaned from debris, then soaked in water for overnight. Dead seeds were removed, then boiled in water $15 \mathrm{~min}$. After cooling, the seeds were transferred to around bottle by occupying $2 / 3$ of its volume and mixed with calcium carbonate $2 \%(\mathrm{w} / \mathrm{w})$ and calcium sulphate $1 \%(\mathrm{w} / \mathrm{w})$. Bottles were then sterilized, for $1 \mathrm{hr}$ at $121^{\circ} \mathrm{C}$. After cooling, the sterilized bottles were inoculated with mycelial discs (5 $\mathrm{mm}$ diameter) which were born from the margins of 6 days old culture of Pleurotus ostreatus. The inoculated bottles were incubated at $25{ }^{\circ} \mathrm{C}$ for $15-20$ days. The grains master spawn was used to inoculate bags containing $(100 \mathrm{~g})$ pasteurized maize stalks.

Solid state cultivation technique: The nutritional upgrading trial of rice straw or banana leaves were carried out in plastic bags containg $100 \mathrm{~g}$ of rice straw or banana leaves (straw or leaves of $1-2 \mathrm{~cm}$ length were pasteurized in hot water $90{ }^{\circ} \mathrm{C}$ for 2 hrs.). The moisture content of rice straw or banana leaves were adjusted to $70 \%$. The bags were inoculated with $10-12 \mathrm{~g}$ Pleurotus ostreatus spawn, in combined mixture with water hyacinth leaves $(5,10,15,20,25$ and $30 \mathrm{~g} / 100 \mathrm{~g}$ rice straw or banana 
leaves) for each bag. The inoculated bags were incubated on $28{ }^{\circ} \mathrm{C}$ for 28 days (Darwish, 2000).

Preparation of water hyacinth binary mixtures: After chopped rice straw or banana leaves different combinations with water hyacinth leaves with different ratios $(5,10,15,20,25$ and $30 \mathrm{gm}$ of water hyacinth leaves/100 gm rice straw or banana leaves). These combinations were made to explore their effect on nutritive value and digestibility.

\section{Chemical analytical methods}

Moisture content, ash, crude fiber, crude protein ether extract, neutral and acid detergent fiber were determined according to separate methods described in AOAC (2002). Total hydrolyzable carbohydrates were determined according to Montgomery (1961). Lignocellulosic fractions based on dry matter basis were determinted according to the method of Van Soest and Robertson (1980).

\section{In vitro disappearance}

The in vitro dry matter disappearance (DMD) and organic matter disappearance (OMD) of samples were determined according to the two stages technique described by Tilley and Terry (1963). The rumen liquor was collected from fistulated sheep fed ration consisted of $70 \%$ wheat straw, $15 \%$ alfalfa hay and $15 \%$ concentrate feed mixture.

\section{Statistical analysis}

Statistical analysis for each separate collected data was done according to Gomez and Gomez (1984). The treatment means were compared using the least significant difference test (LSD) at the $5 \%$ level of probability as out lined by Waller and Duncan (1969).

\section{RESULTES AND DISCUSSION}

The chemical composition of these materials aregiven in Table 1\&2 showing the limiting factors for their utilization by ruminants are low crude protein, high fiber and low available energy contents.

Data in Tables $(1 \& 2)$ show the biological treatment of rice straw and banana leaves by using different amounts of Pleurotus ostreatus inoculum, in solid state cultivation techniques. The obtained results revealed a significant increase $(p<0.05)$ of crude protein content in all treated samples, compared to control. The highest protein contents being $7.90 \%$ and $16.02 \%$ were obtained when rice straw and banana leaves were fermented using Pleurotus ostreatus for 28 days, respectively. Commonly, the protein content was increased in all treatments including both Pleurotus ostreatus compared treatment of rice straw and banana leaves without Pleurotus ostreatus.

The fiber fractions content decreased in all treatments with most significant decrease noted for all treatments compared to control 
The obtained results also showed a decrease in cellulose and hemicelluloses contents compared to control. Gradual decrease in lignin content was noticed during different incubation periods. The extent of lignin degradation could be attributed to the ability of Pleurotus ostreatus to produce lignin degraded enzyme such as lignin peroxidase and manganese peroxidase which aid enzymatic degradation (Nerude and Misarcova,1995).

The review of the results indicates that rice straw and rice hulls are deficient in protein, energy, and minerals and their nutritive values are quite low. Physical, chemical and microbiological methods have been investigated to improve the digestibility and nutritive value of these by-products. Supplementation with energy, protein, minerals and vitamins resulted in improving the utilisation of the roughages.

In vitro dry matter disappearance (IVDMD) and in vitro organic matter disappearance ( IVOMD ) revealed their maximum values for treatment rice straw being $26.74 \%$ and 50.20 $\%$, respectively, compared to control being $29.68 \%$ and $56.60 \%$, when added $10 \mathrm{~g}$ inoculumof Pleurotus ostreatus ,but being $29.55 \%$ and $50.20 \%$, respectively, compared to control being $31.60 \%$ and $56.20 \%$, in banana leaves when added $12 \mathrm{~g}$ inoculum of Pleurotus ostreatus

These obtained results came in agreement with those reported of by Mukherjee and Nandi (2004), Vijaya et al (2006) and Guides et al (2008), as they found that lignin decomposition ( delignification ) by fungus consequently leads to an increase in (IVDMD) which is considered a positive change in increasing the overall digestibility of feed composition. Zadrazil and Kamra (1989) reported improvement of in vitro digestibility after fermentation with Pleurotus spp.

In addition, these residues are needed to increase protenuaus compounds. This native composition of the crop residues make them unsuitable for animal feeding. Therefore, water hyacinth leaves should be take place, by mixing with rice straw and banana leaves with different ratios $(5,10,15,20,25$ and $30 \mathrm{~g} / 100 \mathrm{~g}$ substrate), it could be cleared that water hyacinth leaves contain high amounts of crude protein and minerals, in this study we made treatments combination of rice straw, banana leaves and water hyacinth leaves to upgrade the nutritive value and in vitro digestibility to possible can be used as fodder ruminants. Improving the digestibility and nutritive value of rice straw, banana leaves by using combination mixture technique, was accomplished. The structural chemical changes in the components of the resulted product were evaluated (Tables 3 \&4).

The obtained results revealed increasing of crude protein in all treatments in comparison with control. High protein content being $10.00 \%$ and $17.10 \%$ when mix $30 \mathrm{~g}$ of water hyacinth leaves with $100 \mathrm{~g}$ rice straw or banana leaves, respectively. Commonly, the protein content increased with all treatments. Similar results were reported by Abd El-Rahman (1996), El-Shaer et al., (2005) and Abd El-Hamid et al., (2006).

The obtained results also revealed that crude fiber decreased with all treatments. Decrease in crude fiber values as responsibility of mixing was reported by Rogosic et al., (2005) and Boghuhn et al., (2006).

$$
\text { rr. }
$$


The obtained results also confirmed a decrease in fiber fractions contents. Cellulose and hemicellulose were also decreased with all tested treatments, whereas they decrease from $33.30 \%$ and $27.50 \%$ to $21.74 \%$ and $11.71 \%$, respectively, when mixed $30 \mathrm{~g}$ of water hyacinth leaves with $100 \mathrm{~g}$ of rice straw, however, they being $16.88 \%$ and $8.97 \%$, respectively, when mixed $30 \mathrm{~g}$ of water hyacinth leaves with $100 \mathrm{~g}$ of banana leaves. It was interested to determine gradual decrease in lignin in course of different ration. Degradation of lignin resulted in increasing of in vitro digestibility of rice straw, banana leaves and water hyacinth leaves mixture and confirming their uses as feed for ruminant animals. These results are in agree with the findings of Blummel and Becker (1997); Allam et al., (2006) and Patra (2007).

In vitro dry organic matter disappearance (IVOMD) showed high significant $(\mathrm{P}<0.05)$ increase. In general, the obtained results cleared these treatment succeeded to improve the nutritive value of rice straw, banana leaves and water hyacinth leaves mixture to be used for ruminant feeding. These results are agreement with Khattab et al,. (1999); Patra et al., (2006); Darwish and Ali (2005); Agarwal et al., (2006); Chumpawadee et al., (2007); Sallam et al., (2007) and Darwish and Bakr (2010)-

\section{CONCLUSION}

This study indicated that treatments of rice straw or banana leaves as agricultural by product with combination water hyacinth leaves and Pleurotus ostreatus can increase crude protein and improve digestion. Furthermore, this study opened useful applied access for production of rice straw or banana leaves based products of good quality. Moreover, the current study can add applied values based on fungal treatment of non beneficial agricultural waste. 
Journal of Environmental Studies and Researches (2017), 6(E2):226-241

Table (1) : Biological treatment of rice straw using different amounts of *Pleurotus ostreatus inoculum in solid state fermentation technique ( incubated at $28^{\circ} \mathrm{C}$ for 4- weeks )

\begin{tabular}{|c|c|c|c|c|c|c|c|c|c|c|c|c|c|c|}
\hline \multirow{2}{*}{$\begin{array}{l}\text { Fungal } \\
\text { inoculu } \\
\text { m } \\
\text { amounts } \\
\quad \text { (g) }\end{array}$} & \multirow{2}{*}{\begin{tabular}{|l} 
Biomas \\
s \\
recover \\
y (g)
\end{tabular}} & \multicolumn{2}{|c|}{$\begin{array}{l}\begin{array}{l}\text { Crude } \\
\text { protein } \\
\text { obtained }\end{array} \\
\end{array}$} & \multirow{2}{*}{$\begin{array}{l}\text { Net } \\
\text { gaine } \\
\text { d } \\
\text { protei } \\
\text { n (g) }\end{array}$} & \multirow{2}{*}{$\begin{array}{l}\text { Fungal } \\
\text { mycelial } \\
\text { dry wt. } \\
\text { (g/100g) }\end{array}$} & \multirow{2}{*}{$\begin{array}{l}\text { Undegrade } \\
\text { d substrate } \\
\text { (g) }\end{array}$} & \multirow{2}{*}{$\begin{array}{l}\text { Degrade } \\
\text { d } \\
\text { substrate } \\
\text { (g) }\end{array}$} & \multirow[t]{2}{*}{\begin{tabular}{|ll}
\multicolumn{3}{|c|}{ Bioconversi } \\
on & efficiency \\
(g) &
\end{tabular}} & \multicolumn{2}{|c|}{$\begin{array}{ll}\begin{array}{l}\text { In vitro } \\
\text { disappearan }\end{array} \\
\text { ce }\end{array}$} & \multicolumn{4}{|c|}{ Chemical analysis of biomass recovery } \\
\hline & & $\%$ & (g) & & & & & & DMD & DM $^{\text {OM }}$ & $\begin{array}{l}\text { Hemi- } \\
\text { cellulose } \\
\%\end{array}$ & $\begin{array}{l}\text { Cellulose } \\
\%\end{array}$ & Lignin\% & $\%{ }^{\text {Ash }}$ \\
\hline $2 \mathrm{gm}$ & 74.24 & 2.80 & 2.10 & 0.50 & 1.43 & 72.81 & 27.19 & 1.84 & 40.20 & 41.80 & 28.10 & 35.10 & 9.90 & 16.80 \\
\hline $4 \mathrm{gm}$ & 75.30 & 4.70 & 3.54 & 2.40 & 6.86 & 68.44 & 31.56 & 7.61 & 42.60 & 45.50 & 22.90 & 35.20 & 9.30 & 17.10 \\
\hline $6 \mathrm{gm}$ & 76.24 & 4.90 & 3.74 & 2.60 & 7.43 & 68.81 & 31.19 & 8.34 & 46.10 & 48.20 & 23.30 & 33.80 & 9.10 & 17.30 \\
\hline $8 \mathrm{gm}$ & 78.20 & 6.30 & 4.93 & 4.00 & 11.43 & 66.77 & 33.23 & 12.04 & 46.30 & 48.20 & 22.70 & 33.00 & 8.10 & 17.50 \\
\hline $10 \mathrm{gm}$ & 76.00 & 7.90 & 6.00 & 5.60 & 16.00 & 60.00 & 40.00 & 14.00 & 50.20 & 56.60 & 20.20 & 31.30 & 8.30 & 18.00 \\
\hline $12 \mathrm{gm}$ & 77.02 & 7.80 & 6.01 & 5.50 & 15.71 & 61.31 & 38.69 & 14.22 & 55.55 & 59.10 & 19.00 & 31.00 & 8.85 & 18.10 \\
\hline **Control & 100.00 & 2.30 & 2.30 & _- & _- & 100.00 & _- & _ & 26.74 & 29.68 & 27.50 & 33.30 & 11.60 & 16.70 \\
\hline
\end{tabular}

Table 1 (Continued; Foot notes)

$a, b, c \ldots . . .$. Means in the same column with different superscripts significantly different $(\mathrm{p}<0.05)$

IVDMM in vitro dry matter disappearance

IVOMD in vitro organic matter disappearance *Crude protein content of Pleurotus ostreatus (35\%) 
Table (3) : Biological treatment of rice straw and water hyacinth leaves mixture by using *Pleurotus ostreatus in solid state fermentation (incubated at $28^{\circ} \mathrm{C}$ for 4- Weeks)

\begin{tabular}{|c|c|c|c|c|c|c|c|c|c|c|c|}
\hline \multirow[t]{2}{*}{$\begin{array}{l}\text { Fermented media } \\
\text { mixture ratio }\end{array}$} & \multirow[b]{2}{*}{ Dry matter $\%$} & \multirow{2}{*}{$\begin{array}{l}\text { Total } \\
\text { hydrolysable } \\
\text { carbohydrates }\end{array}$} & \multirow[b]{2}{*}{$\begin{array}{l}\text { Ether } \\
\text { extract }\end{array}$} & \multirow[b]{2}{*}{$\begin{array}{l}\text { Crude } \\
\text { protein }\end{array}$} & \multirow[b]{2}{*}{$\begin{array}{l}\text { Crude } \\
\text { Fiber }\end{array}$} & \multicolumn{2}{|c|}{$\begin{array}{c}\text { In vitro } \\
\text { disappearance }\end{array}$} & \multicolumn{4}{|c|}{$\begin{array}{l}\begin{array}{c}\text { Chemical analysis of biomass } \\
\text { recovery }\end{array} \\
\end{array}$} \\
\hline & & & & & & DMD & OMD & $\begin{array}{l}\text { Hemi- } \\
\text { cellulo } \\
\text { se } \%\end{array}$ & $\begin{array}{l}\text { Cellul } \\
\text { ose } \%\end{array}$ & $\begin{array}{l}\text { Lignin } \\
\%\end{array}$ & $\begin{array}{l}\text { Ash } \\
\%\end{array}$ \\
\hline $\begin{array}{l}\text { *Rice straw(RS) } \\
\text { (control)untreated }\end{array}$ & 86.60 & 34.10 & 1.20 & 2.30 & 39.40 & 26.74 & 29.68 & 27.50 & 33.30 & 11.60 & 16.70 \\
\hline $\begin{array}{c}* * \text { Water hyacinth } \\
\text { leaves }(\mathrm{Wh}) \text { untreated }\end{array}$ & 85.87 & 32.50 & 3.05 & 20.90 & 20.80 & 40.44 & 52.81 & 13.64 & 15.15 & 5.73 & 17.99 \\
\hline $\mathrm{RS}+\mathrm{W} \mathrm{h}(5 \%)$ untreated & 85.80 & 25.25 & 1.30 & 3.23 & 38.47 & 42.50 & 46.70 & 18.30 & 35.35 & 13.00 & 17.55 \\
\hline $\mathrm{RS}+\mathrm{W} \mathrm{h}(5 \%)$ treated & 78.50 & 20.01 & 1.54 & 7.40 & 33.86 & 44.30 & 53.20 & 19.32 & 34.72 & 12.27 & 17.60 \\
\hline $\mathrm{RS}+\mathrm{W} \mathrm{h}(10 \%)$ untreated & 83.90 & 22.95 & 1.40 & 5.70 & 37.54 & 42.80 & 48.80 & 20.29 & 33.72 & 11.90 & 17.00 \\
\hline $\mathrm{RS}+\mathrm{W} \mathrm{h}(10 \%)$ treated & 77.16 & 20.72 & 1.47 & 7.50 & 33.12 & 46.30 & 54.80 & 16.47 & 34.89 & 9.99 & 16.35 \\
\hline $\mathrm{RS}+\mathrm{W} \mathrm{h}(15 \%)$ untreated & 83.50 & 23.88 & 1.59 & 6.30 & 36.61 & 42.80 & 46.80 & 17.24 & 31.52 & 7.51 & 16.02 \\
\hline $\mathrm{RS}+\mathrm{W} \mathrm{h}(15 \%)$ treated & 75.51 & 20.00 & 1.63 & 7.60 & 33.07 & 46.50 & 54.70 & 14.18 & 28.39 & 7.05 & 16.23 \\
\hline $\mathrm{RS}+\mathrm{W} \mathrm{h}(20 \%)$ untreated & 82.48 & 23.80 & 1.56 & 6.50 & 35.68 & 42.90 & 47.80 & 14.11 & 25.72 & 6.33 & 15.95 \\
\hline $\mathrm{RS}+\mathrm{W}$ h $(20 \%)$ treated & 72.00 & 16.59 & 1.64 & 7.90 & 31.88 & 47.40 & 55.10 & 13.56 & 23.19 & 5.58 & 15.99 \\
\hline
\end{tabular}


osama hassan mohamed et al.

\begin{tabular}{|lrr|l|l|l|l|l|l|l|l|l|l|l|}
\hline $\begin{array}{l}\text { RS+W } \\
\text { untreated }\end{array}$ & $\mathrm{h}$ & $(25 \%)$ & 81.73 & 23.70 & 1.67 & 6.83 & 34.75 & 43.50 & 48.10 & 14.02 & 21.88 & 5.83 & 16.11 \\
\hline $\begin{array}{l}\text { RS+W } \\
\text { treated }\end{array}$ & $\mathrm{h}$ & $(25 \%)$ & 71.20 & 18.23 & 1.94 & 8.00 & 28.48 & 48.50 & 55.10 & 14.26 & 21.39 & 5.55 & 16.20 \\
\hline $\begin{array}{l}\text { RS+W } \\
\text { untreated }\end{array}$ & $\mathrm{h}$ & $(30 \%)$ & 81.80 & 23.00 & 1.53 & 8.20 & 33.82 & 43.60 & 48.60 & 14.11 & 22.00 & 6.10 & 16.43 \\
\hline $\begin{array}{l}\text { RS+W } \\
\text { treated }\end{array}$ & $\mathrm{h}$ & $(30 \%)$ & 70.00 & 17.21 & 1.69 & 10.00 & 25.37 & 49.50 & 55.70 & 11.71 & 21.74 & 5.59 & 16.73 \\
\hline
\end{tabular}

Table 3 (Continued; Foot notes)

$\mathrm{a}, \mathrm{b}, \mathrm{c} \ldots \ldots .$. Means in the same column with different superscripts significantly different $(\mathrm{p}<0.05)$

* RS Rice Straw without any treatment

**W h Water hyacinth leaves without any treatment

IVDMM in vitro dry matter disappearance

IVOMD in vitro organic matter disappearance

Table (2) : Biological treatment of banana leaves using different amounts of *Pleurotus ostreatus inoculums 
in solid state fermentation technique ( incubated at $28^{\circ} \mathrm{C}$ for 4 - weeks )

Table 2 (Continued; Foot notes)

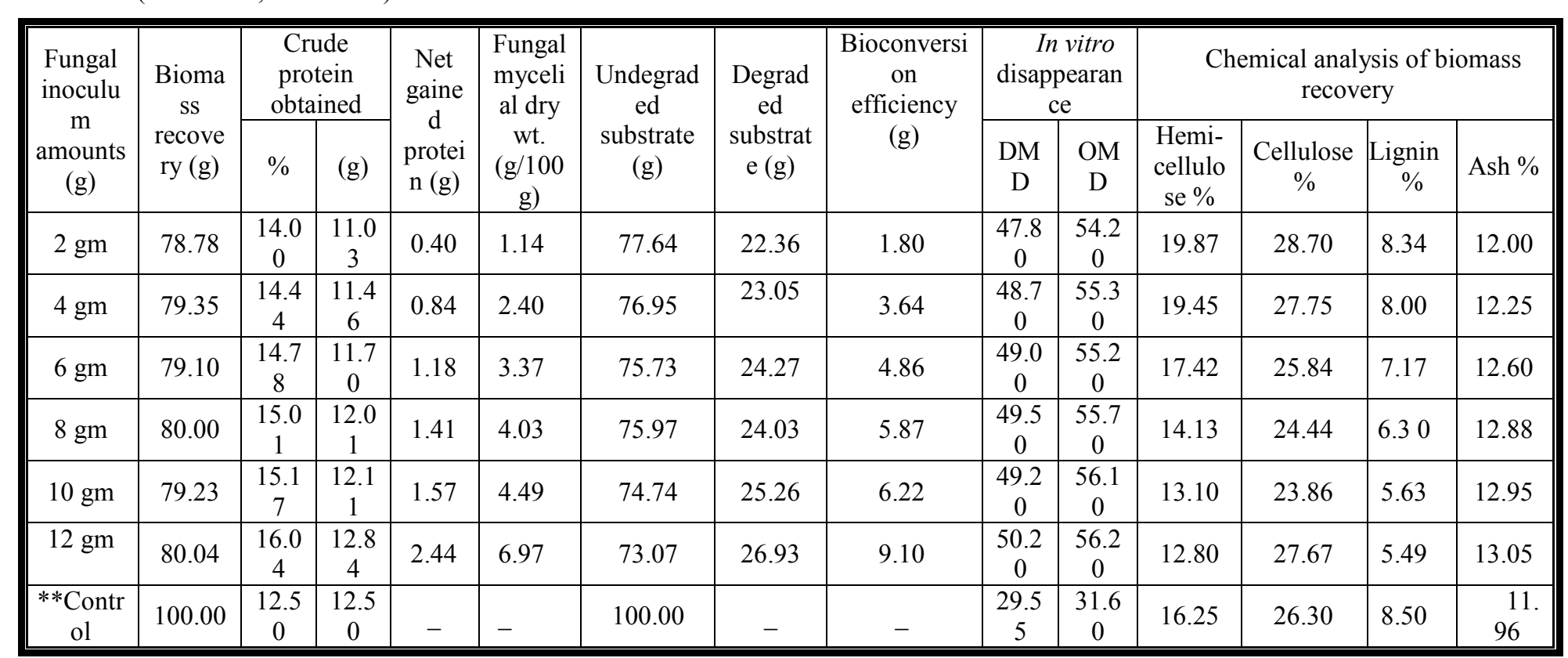

$a, b, c \ldots . . .$. Means in the same column with different superscripts significantly different $(p<0.05)$ IVDMM in vitro dry matter disappearance IVOMD in vitro organic matter disappearance

***Control treatment (untreated banana leaves) Crude protein content of Pleurotus ostreatus (35\%) ro 
osama hassan mohamed et al.

Table (4) : Biological treatment of banana leaves and water hyacinth leaves mixture by using *Pleurotus ostreatus in solid state fermentation (incubated at $28^{\circ} \mathrm{C}$ for 4- Weeks)

\begin{tabular}{|c|c|c|c|c|c|c|c|c|c|c|c|}
\hline \multirow[b]{2}{*}{ Fermented media mixture ratio } & \multirow{2}{*}{$\begin{array}{l}\text { Dry } \\
\text { matter\% }\end{array}$} & \multirow{2}{*}{$\begin{array}{l}\text { Total } \\
\text { hydrolysab } \\
\text { le } \\
\text { carbohydr } \\
\text { ates }\end{array}$} & \multirow{2}{*}{$\begin{array}{l}\text { Ether } \\
\text { extract }\end{array}$} & \multirow{2}{*}{$\begin{array}{l}\text { Crude } \\
\text { protein }\end{array}$} & \multirow{2}{*}{$\begin{array}{l}\text { Crude } \\
\text { Fiber }\end{array}$} & \multicolumn{2}{|c|}{$\begin{array}{l}\text { In vitro } \\
\text { disappearance }\end{array}$} & \multicolumn{4}{|c|}{ Chemical analysis of biomass recovery } \\
\hline & & & & & & $D M D$ & OMD & $\begin{array}{l}\text { Hemi- } \\
\text { cellulose \% }\end{array}$ & $\begin{array}{l}\text { Cellul } \\
\text { ose } \%\end{array}$ & Lignin $\%$ & Ash \% \\
\hline $\begin{array}{l}\text { *Banana } \\
\text { leaves }(\mathrm{Bl})(\text { control)untreated }\end{array}$ & 88.40 & 38.55 & 1.75 & 12.50 & 28.50 & 29.55 & 31.60 & 16.25 & 26.30 & 8.50 & 11.96 \\
\hline $\begin{array}{ll}* * \text { Water } & \text { hyacinth } \\
\text { leaves(Wh)untreated }\end{array}$ & 85.87 & 32.50 & 3.05 & 20.90 & 20.80 & 40.44 & 52.81 & 13.64 & 15.15 & 5.73 & 17.99 \\
\hline $\mathrm{Bl}+\mathrm{W}$ h $(5 \%)$ untreated & 85.98 & 30.55 & 2.02 & 12.93 & 28.22 & 49.10 & 54.60 & 15.68 & 24.46 & 9.60 & 12.26 \\
\hline $\mathrm{Bl}+\mathrm{W} \mathrm{h}(5 \%)$ treated & 78.20 & 23.99 & 2.20 & 14.10 & 25.49 & 52.60 & 58.20 & 14.38 & 22.96 & 9.10 & 13.42 \\
\hline $\mathrm{Bl}+\mathrm{W} \mathrm{h}(10 \%)$ untreated & 86.59 & 29.50 & 2.32 & 13.34 & 27.90 & 49.50 & 55.70 & 15.54 & 23.47 & 9.46 & 13.60 \\
\hline $\mathrm{B} 1+\mathrm{W}$ h $(10 \%)$ treated & 77.14 & 21.00 & 2,58 & 15.40 & 24.44 & 54.60 & 59.60 & 14.52 & 22.65 & 8.99 & 13.95 \\
\hline $\mathrm{Bl}+\mathrm{W} \mathrm{h}(15 \%)$ untreated & 81.04 & 23.10 & 2.40 & 13.77 & 27.60 & 55.60 & 59.80 & 14.02 & 22.57 & 8.18 & 14.20 \\
\hline $\mathrm{Bl}+\mathrm{W} \mathrm{h}(15 \%)$ treated & 76.00 & 19.05 & 2.95 & 15.80 & 23.81 & 56.20 & 60.20 & 12.41 & 20.10 & 7.39 & 14.47 \\
\hline $\mathrm{Bl}+\mathrm{W} \mathrm{h}(20 \%)$ untreated & 84.83 & 25.90 & 2.73 & 14.18 & 27.30 & 53.80 & 59.60 & 11.80 & 21.00 & 7.37 & 14.70 \\
\hline $\mathrm{Bl}+\mathrm{W} \mathrm{h}(20 \%)$ treated & 75.50 & 18.00 & 3.30 & 16.70 & 22.92 & 54.20 & 60.10 & 11.25 & 19.35 & 6.30 & 15.30 \\
\hline $\mathrm{Bl}+\mathrm{W}$ h (25\%) untreated & 81.43 & 22.22 & 2.77 & 14.60 & 27.00 & 54.20 & 60.60 & 10.90 & 19.00 & 6.00 & 14.95 \\
\hline
\end{tabular}


Journal of Environmental Studies and Researches (2017)

\begin{tabular}{|c|l|l|l|l|l|l|l|l|l|l|l|}
\hline Bl+W h (25\%) treated & 73.85 & 16.10 & 3.45 & 17.00 & 21.90 & 60.60 & 54.20 & 10.55 & 17.85 & 5.85 & 15.90 \\
\hline Bl+W h (30\%) untreated & 79.51 & 19.65 & 2.98 & 15.02 & 26.60 & 54.70 & 56.77 & 10.34 & 17.15 & 5.75 & 15.29 \\
\hline Bl+W h (30\%) treated & 71.24 & 14.44 & 3.84. & 17.10 & 19.78 & 61.90 & 54.60 & 8.97 & 16.88 & 5.35 & 16.10 \\
\hline
\end{tabular}

Table 4 (Continued; Foot notes)

$a, b, c \ldots . . .$. Means in the same column with different superscripts significantly different $(p<0.05)$

* B1 Banana leaves without any treatment

**W h Water hyacinth leaves

IVDMM in vitro dry matter disappearance IVOMD in vitro organic matter disappearance 


\title{
REFERENCES
}

\author{
Abd-El-Gawad, A.M.; W.H.Abd-El-Malek; M. Sabbah Allam and I.M. El-Sayed, 1994: \\ Utilization of banana, tomato and potato by- products by sheep. Egyptian J. Anim. Prod., \\ 31:215.
}

\begin{abstract}
Abd El-Ghani, N. T. and Elchaghaby, G.A. (2007). In fluence of operating conditions on the removal of $\mathrm{Cu}, \mathrm{Zn}$. $\mathrm{Cd}$ and $\mathrm{Pb}$ ions from waster water by adsorption. Int. J. Environ. Sci. Tech., 4 (4): 451-456.
\end{abstract}

Abd El-Hamid, A. M.; Afaf, M.Fayed; Ghanem, A.Z. and Helal, H.G. (2006). Studies on biological treatments of salt plants. I. Feed evaluation by small ruminates. J. Agric. Sci., Mansoura Univ., 31 (2): 62-70.

\begin{abstract}
Abd El-Rahman, H.H. (1996). Utilization of desert range poor quality feeds by sheep and goats. M.Sc., Thesis Fac. Of Agric., Cairo Univ. Egypt.
\end{abstract}

Abia, A.A.; Horsfall, M. Jr. and Didi, O. (2002). Studies on the use of agricultural by products for the removal of trace metals from aqueous solution. J. Appl. Sci. Environ. Manage., 6, 89-99.

\begin{abstract}
Agarwal, N.; Kamra, D.N. Chaudhary, L.C. and Patra, A.K. (2006). Effect of Sapindus mukorossi extracts on in vitro methan ogenesis and fermentation characteristic in buffalo rumen liquor. J. Appl. Animal Res., 30:1-4.
\end{abstract}

Allam, S.M.; Yossef, K.M.; Ali, M.A. and Abo Bakr, S.Y. (2006). Using some fodder shrubs and industrial by products in different forms for feeding goats in Sirai. J. Agric. Sci. Mansoura Univ., 31(3): 1371-1385.

AOAC (2002). Official Methods of Analysis of Association of Official Agriculture Chemists International $11^{\text {th }}$ Ed., Washington.

Baguhn, J.; Kluth, H. and Rodehuts Cord, M. (2006). Effect of total mixed ration composition on fermentation efficiency of ruminal microbial crude protein synthesis in vitro. $\mathrm{J}$. Dairy Sci., 89:1580-1591.

Blummel, M. and Becker, K. (1997). The degradability characteristic of fifty four roughages and roughage neutral detergent fiber as described in vitro gas production and their relationship to voluntary feed intake. British Journal of Nutrition. 77:757-768.

Chumpawadee, S.; Chantiratikul, A. and Chantiratikul, P. (2007). Chemical composition and Nutritional evaluation of energy feeds for ruminant using in vitro gas production technique. Pakistan Journal Nutrition, 6 (6): 607-612.

Darwish G.A.M.A. (2000). Biochemical Treatments for Nutritional Upgrading of some Agricultural Crop Residues.pp.70-84. Ph.D.Thesis, Faculty of Agriculture, Cairo University, Egypt. 
Darwish G. A.M.A. and Ali M.A. (2005) .Improving the Efficiency of Fungal Treatment of Banana Wastes Used as Animal Feed. J.Biol.Pharm.Sci. 3(1):62-72.

Darwish G. A.M.A. and Bakr A.A.(2010). Nutritional upgrading of wheat straw as Animal Feed. Egypt.J.Microbiol. 27:171-181.

Difco Manual (1979). Dehydrated Culture Media Reagent for Microbiology, 10th Edition,USA. pp. 689-691.

El-Sayed, H.M.; El-Ashry, M,A,; Metwally, H.M.; Fadel, M.and . Khorshed, M.M.(2002). Effect of chemical and biological treatments of some crop- residues on their nutritive value.3Digestion coefficients, rumen and blood serum parameters of goats. J. Nutr. And Feed,5(1): 5569.

El-Shaer, H.M.; Li, F.T.; Nadia Morcos, Y.S.; Shalabia Emam, S. and Abeer Esawy, M. (2005). Seasonal changes of some anti-nutritional factors contents of some halophytic shrubs and the effect of processing treatments on their utilization by sheep under desert conditions of Egypt. Egypt. J. Nutrition and Feed (Special Issue) 8 (1): 417-431.

Etman, K.E.I.; T.I. El-Monayer; A.M.M. Zeid; Ebtehag, I.M. Abou-Elenin and S.K. Sayed. (2011). Utilization of new nutritional resources in ruminant feeding(2) Effect of using dried distillers grains with soluble (DDGS) as protein source in rations for fattening buffalo calves.J. Anim. And Poultry Prod., Mansoura Univ., Vol. 2 (6): 201-215.

Gomez, K.A. and Gomez. A.A. (1984). Statistical Procedures for Agricultural Research. John Wiley and Sons Inc., USA.

Guides C.M., Gonalves D., Rodrigues M.A.M. and Dias-Da-Silva A. (2008).Effect of Saccharomyes cerevisiae in the Degradation (maize silage) in Cows. Anim. Feed. Sci. Technol., 14 (5):27-40.

Khattab, H.M.; El Sayed, H.M. and Abo EINor, S.A.H. (1999). Evaluation of an agroindustrial by-products mixture Fed to goats. Egypt. J. Nutrition and Feed, 2: 243-252.

Khattab, H.M.; A.M. Kholif; H.A. El-Alamy; F.A. Salem and A.A/ El-SHEWY, 2000: Ensiled banana wastes with molasses or whey for lactating buffaloes during early lactation. Asian. J. Anim. Sci.,13:619.

Leupp,J.L.; G.P. Lardy; K.K. Karges; M.L. Gibson and T.S. Caton(2009). Effect of increasing level of corn distillers dried grains with soluble on intake, digestion and ruminal fermentation in steers fed seventy percent concentrate diets. J. Anim. Sci., 87:206.

May, M.L.; M.J. Quinn; B.E. Depenbusch; C.D. Reinhanrd; L. Gibson; K.K. Karges; N.A. Cole and J.S. Drouillard (2009). Dried distiller grains with soluble with reduced corn silage level in beet finishing diets. J. Anim. Sci., Vol.(10):2527. 
Mohi, El-Din, A.M.A.; FAthia, A.I. and E.E. Ragheb (2008). Effect of using natural feed additives on feed utilization and growth performance of growing Friesian calves . Egyptian J. Nurt. And Feeds,11 (1): 159-170.

Montgomery R. (1961). Further Studies of Phenol Sulphuric Acid Reagent for Carbohydrates. Biochem. Biophys. Acta 84:591-593.

Mukherjee R. and Nandi B. (2004). Improvement of in vitro Digestibility through Biological Treatment of Water Hyacinth Biomass by Two Pleurotus species. International Biodeterioration and Biodegradation 53 (1) :7-12.

Nerude F. and Misurcova A. (1995). Distribution of Lignolytic Enzyme in Selected White Rot Fungi. Folia Microbiology. 4 (3): 264-266.

Patra, A.K. (2007). Nutritional management in organic livestock farming for improved ruminant health and production-an over view Live stock Research for Rural Development, 19 Artica $11 \# 41$.

Patra, A.K.; Kamra, D.N. and Agarwal, N. (2006). Effect of plant extracts on in vitro methanogenesis, enzyma activities and fermentation of feed in rumen liquor of buffalo. Animal Feed Science and Technol., 128: 276-291.

Rogosic, J.; Pfisterand, J.A. and Provenza, F.D. (2005). The effect of poly ethylene glycol on intake of Mediterranean shrubs by sheep and goats. Range land Ecol. Manag. (In press).

Sallam, S.M.A.; Nasser, M.E.A.; EI Waziry, A.M.; Bueno, I. C.S. and Abdalla, A. L. (2007). Use of an in vitro ruminant gas production technique to evaluate some ruminant feeds stuffs. J. of Applied Sciences Resources, 3 (1): 33-41.

Shwerab, A.M.; Khalel, M.S.; Hassan, A.A.; Amany, A. Khayyal and Yacout, M.H.(2012). Optimizing the use of corn dried distillers grain with soluble in sheep production. Egyptian J. Nutrition and Feeds, 13 (3):415-431.

Singh, K.K.; Rastogi, R. and Hasan, S.H. (2005). Removal of cadmium from waste water using agricultural waste rice polish. J. Hazard. Mater., 121, (1-3), 51-58.

Tilley J. M.A. and Terry R.A. (1963). A Two-stage Technique for the In- vitro Digestion of Forage Crops. J. British Grassland Society. 18 (21): 104-111.

Van Soest P.J. and Robertson J.B. (1980). In: Standardization of Analytical Methodology for Feeds, pp. 49-60, (eds.) Pidgen W.J., Balchand C.C., Graham M. IDRC Publ. 134 e, International Development Research Center, Ottawa,

Vijaya C., Singaracharya M.A., Vijaya Lakshni V., Mangamoori L.N. and Ramireddy M.R. (2006). Use of Lignocelluolytic Mutants of Pleurotus ostreatus in Ruminant Feed Formulations. Bioresources , 4 (1): 142- 154. 
Vijaya Panjabrao Mane, Shyam Sopanrao Patil, Abrar Ahmed Syed and Mirza

Mushtaq Vaseem Biag. (2007). Bioconversion of Low Quality Lignocellulosic Agricultural

Waste into Edible Protein by Pleurotus sajor-caju (Fr.) Singer. J. Zhejiang Univ. Sci. B. 8 (10): 745-751.

Waller R.A. and Duncan D.B. (1969). A Boyes Role for Symmetric Multiple Comparisons Problems. J. Am. Statist. Assoc. 64: 1484-1503.

Zadrazil F . and D. N. Karma (1989) . Influence of Air and Oxygen Supply on Lignin Degradation and its Relation with an In- vitro Digestibility of Wheat Straw Fermented with Stropharia rugusonnulata, Pleurotus eryngii and P.sajor-caju mushroom. J.Tropics 2: $79-88$. 